\title{
Efficacy of Different Forms of Green Manure Crops to Reduce Verticillium dahliae in Different Soils
}

\author{
Swann Dalbard and Vincent V. Michel ${ }^{*}$ \\ Agroscope Research Center, 1964 Conthey, Switzerland
}

\section{ARTICLE INFO}

Article Type: Research Article

Keywords:

Rye

Streptomyces

Brassica juncea

Sorghum-sudangrass

Soil microbial activity

Timeline:

Received: September 20, 2021

Accepted: October 10, 2021

Published: November 15, 2021

Citation: Dalbard S, Michel $\vee$ V. Efficacy of Different Forms of Green Manure Crops to Reduce Verticillium dahliae in Different Soils. Glob J Agric Innov Res Dev. 2021; 8: 191-205.

DOl: https://doi.org/10.15377/2409-9813.2021.08.15

\begin{abstract}
The efficacy of green manure crops to reduce the number of Verticillium dahliae microsclerotia in different soils was investigated. Green manures tested were Indian mustard with a high glucosinolate content and sorghum-sudangrass as biocidal plants, and Indian mustard with a low glucosinolate content and rye as non-biocidal plants. The green manure plants were applied in fresh, dried, and ensilaged form. When applied as fresh plants, the glucosinolate content determining the biocidal activity of Indian mustard was only important in loam soil but not in sandy loam soil. In the latter soil, the non-biocidal rye had significantly higher efficacy than the Indian mustard. Volatiles released by fresh and dried, but not ensilaged, Indian mustard with a high glucosinolate content strongly decreased the number of living $V$. dahliae microsclerotia. When the same green manure crops were added to sandy loam and clay loam soil, the effect of the high glucosinolate content Indian mustard in fresh and dried form disappeared, whereas the ensilaged green manure crops had the highest efficacy. This effect was based on the increase of the soil microbial activity and the Streptomyces population size, which were negatively correlated with the number of living $V$. dahliae microsclerotia in the soil.
\end{abstract}

*Corresponding Author Email: vincent.michel@agroscope.admin.ch Tel: +41791573433

(c) 2021 Dalbard and Michel. Published by Avanti Publishers. This is an open access article licensed under the terms of the Creative Commons Attribution Non-Commercial License which permits unrestricted, non-commercial use, distribution and reproduction in any medium, provided the work is properly cited. (http://creativecommons.org/licenses/by-nc/4.0/) 


\section{Introduction}

One of the most important soilborne diseases worldwide is Verticillium wilt, caused mainly by Verticillium dahliae Kleb. [1]. More than 400 plant species are known to be host plants of $V$. dahliae [2], and new host plant species are detected continuously. Economic losses are significant in high-value horticultural crops. A highly effective way to control Verticillium wilt is using chemical fumigants, especially methyl bromide [1]. With the phasing-out of methyl bromide in 2005 [3], the research for alternative methods to control soilborne diseases became important. Among the promising alternatives to control $V$. dahliae and other major soilborne pathogens is the use of green manures [4]. Especially interesting is the concept of biofumigation, which is based on the application of plant species that release volatile biocidal molecules after their incorporation into the soil [5]. The term biofumigation describes in the first line the use of glucosinolate (GSL) containing cruciferous species, which release isothiocyanates (ITC) during their decomposition [6]. Other plants that contain biocidal molecules are species of the genus Sorghum containing the glucoside dhurrin, which can be degraded in hydrogen cyanide [7]. Green manures do not affect soilborne pathogens through the generation of biocidal molecules only. They also affect the soil microbial communities by the release of easily degradable organic molecules during their breakdown. The thereby initiated stimulation of the soil microbial activity is the major driver of soil fungistasis [8]. The reduction of fungal pathogens in the soil by incorporating green manures or plant-derived products is partly caused by the increase of specific groups of antagonistic microorganisms. One such group is Streptomyces, whose inhibitory activity was increased after incorporating green manure crops in the soil [9].

In Europe, green manures are mainly used to cover the soils during the fall and winter seasons with the goal of reducing soil erosion and nitrate leaching [10]. In contrast, the use of green manures to control soilborne diseases is not widespread. In Switzerland, Verticillium wilt is a major problem for greenhouse vegetables grown in narrow crop frequencies of $V$. dahliae host plants such as tomato (Solanum lycopersicon L.), eggplant (Solanum melongena L.), and lettuce (Lactuca spp.). Horticulturists are reluctant to grow green manures in the greenhouses because it is expensive. Especially in winter, when heating adds additional costs, the greenhouses can be better used to cultivate a saleable crop, such as lettuce or corn salad (Valerianella spp.). Another important horticultural crop threatened by $V$. dahliae in Switzerland is strawberry (Fragaria $\mathrm{x}$ ananassa (Weston) Duch.), for which the major part of the production is based on the use of Frigo plants. The time gap between the end of the harvest (end of May - beginning of June) and the planting of the Frigo plants (end of June) is too short to cultivate green manure. A solution for both cases, i.e., greenhouse vegetables and strawberries, could be applying green manures in dried or ensilaged form. Drying green manures strongly reduces their weight, whereas the interest in silage is the limited loss of plant material, especially leaves.

The control of soilborne pathogens by the addition of organic or inorganic amendments is strongly influenced by the soil texture and organic matter content [11-13]. Including several soil types is, therefore, a prerequisite for the evaluation of the efficacy of green manures to reduce the number of $V$. dahliae microsclerotia in the soil. Such a reduction is negatively correlated to the severity of Verticillium wilt of several horticultural crops [14-15].

This study aims to assess the efficacy of different green manure crops to reduce the number of $V$. dahliae microsclerotia in different soils. The second aspect investigated was the influence of the conservation form of the green manure crops on their efficacy.

\section{Materials and Methods}

\subsection{Plant Species and Soils}

Biocidal plants tested were Indian mustard (Brassica juncea L.) with high GSL-content and sorghum-sudangrass (Sorghum bicolor (L.) Moench x Sorghum sudanese (Piper) Stapf); non-biocidal plants were Indian mustard with low GSL-content, and rye (Secale cereal L.) (Table 1). Different cultivars of Indian mustard with high and low GSLcontent were included to investigate the role of the GSLs of this plant species. Seeds were sown in 3 or 7 liters plastic pots (latter one only for sorghum-sudangrass) filled with a commercial, fertilizer-enriched peat substrate. The pots were placed in a greenhouse for 6 to 10 weeks until the harvest of the plant material. Growth duration 
varied depending on the plant species and the growing season. Temperatures varied between 18 to $25^{\circ} \mathrm{C}$, and additional light was supplemented with high-pressure sodium lamps from 6 am to 6 pm during the winter season. All species, except the high GSL-content Indian mustard cultivars, were supplemented with a $0.1 \mathrm{M} \mathrm{NH}_{4} \mathrm{NO}_{3}$ solution at a weekly interval starting two weeks after sowing. The Indian mustard cultivar with a high glucosinolate content was supplemented with a $0.1 \mathrm{M}\left(\mathrm{NH}_{4}\right)_{2} \mathrm{SO}_{4}$ solution in order to favor the formation of GSLs by a sulfurcontaining fertilizer [16].

Table 1: Plant species used as green manure crops in the experiments.

\begin{tabular}{|c|c|c|c|c|}
\hline Species & Latin Binomial & Cultivar & Breeder \\
\hline \hline Indian mustard & Brassica juncea & ISCI-99 & Triumph Italia, Livorno, Italy \\
\hline Indian mustard & Brassica juncea & Arid & SKP-AAFC, Regina, Canada & High GSL-content ${ }^{a}$ \\
\hline Rye & Secale cereale & Wiandi & KWS Lochow, Bergen, Germany \\
\hline Rye & Secale cereale & Borfuro & Saatzucht Steinach, Steinach, Germany & Forage type \\
\hline Sorghum-sudangrass & Sorghum bicolor $x$ S. sudanense & Susu & Feldsaaten Freudenberger, Krefeld, Germany & Forage type \\
\hline
\end{tabular}

a Patalano, 2004.

The above-ground part of the plants was harvested at the tillering to beginning stem elongation stage $(\mathrm{BBCH}$ 22 to 31) for rye and sorghum-sudangrass and at the beginning to full flowering stage (BBCH 61 to 65) for Indian mustard. Dried plant material was obtained by drying fresh plants immediately after harvest in an oven set at $35^{\circ} \mathrm{C}$ for $48 \mathrm{~h}$. Dry plant material was stored until utilization in tightly closed polyethylene bags in the dark at room temperatures. Ensilage plant material was prepared by cutting fresh plants in $5 \mathrm{~cm}$ long pieces, which were placed in a 1-liter glass jar with metal clamps and a vulcanized rubber gasket lid. The plant material was compacted manually to remove as much air as possible before closing the jar airtight. Jars were then stored until utilization in the dark at room temperature. Silage was prepared several weeks before their intended use to allow the complete fermentation of the plant material.

Soils from four sites were included in the pot trials (Table 2). Sites Epines, Riddes, and Conthey are located in the canton Valais in the southern part of Switzerland. Site Lamothe is the location of the experimental farm of the Ecole d'Ingénieur de Purpan close to Toulouse in the southern part of France. All three Swiss soils were naturally colonized by $V$. dahliae, whereas in the soil Lamothe no $V$. dahliae could be detected. The latter soil was included in this study because it represents as soil with a quite different soil texture compared to the three Swiss soils. After collection of the soils, they were stored moist at $4^{\circ} \mathrm{C}$ in open polyethylene bags or air-dried at room temperature.

Table 2: Soils used in the experiments.

\begin{tabular}{|c|c|c|c|c|c|c|c|}
\hline Site & Soil Type & \% Clay & \% Silt & \% Sand & \% Organic Matter & $\mathbf{p H}^{\mathbf{c}}$ & Soil Use \\
\hline \hline Epines & sandy loam & 6 & 19 & 75 & 2.2 & 7.9 & Experimental farm, open field \\
\hline Riddes & loam & 10 & 48 & 42 & 2.2 & 8.0 & Organic grower, plastic tunnel \\
\hline Conthey & sandy loam & 8 & 20 & 72 & 2.3 & 7.8 & Experimental farm, greenhouse \\
\hline Lamothe & clay loam & 32 & 37 & 31 & 2.4 & 6.6 & Experimental farm, open field \\
\hline
\end{tabular}

aUSDA soil texture scheme.

borganic matter = organic $C * 1.75$.

'Extraction in deionized water 1:2.5 (dry soil $(w)$ : water $(v)$ ).

\subsection{Soil Parameters Analysis}

A dry sieving method was used to determine the number of living $V$. dahliae microsclerotia in the soil. Six weeks after sampling, air-dried soil was sieved at $0.5 \mathrm{~mm}$ mesh size and homogenized. Per soil sample, five $100 \mathrm{mg}$ aliquots were dry-plated [17] on Sorensen's NP-10 semi-selective medium [18]. The NP-10 plates were incubated 
in darkness at $24^{\circ} \mathrm{C}$ for two weeks, after which soil was removed from the medium surface by adding tap water and scraping gently with a glass slide. The number of $V$. dahliae microsclerotia forming colonies was counted under a dissecting microscope.

The number of Streptomyces spp. in the soil was determined by dilution plating using a semi-selective doublelayer agar method [8]. Per soil sample, three air-dried $10 \mathrm{~g}$ aliquots were analyzed. The $10 \mathrm{~g}$ dry soil was added to $90 \mathrm{ml}$ of $0.9 \%$ sterile $\mathrm{NaCl}$ solution in a $250 \mathrm{ml}$ Erlenmeyer flask and shaken at $175 \mathrm{rpm}$ for $1 \mathrm{~h}$. The soil suspension was then serially diluted, and per dilution step, $100 \mu$-aliquots were spread on three water agar (WA) plates. The suspension was completely covered with $5 \mathrm{ml}$ of liquid starch casein agar (SCA; [19]). After solidification of the SCA, the plates were incubated in darkness at $24^{\circ} \mathrm{C}$. After one week, the Streptomyces spp. density expressed as colony-forming units (CFU) per g dry soil was determined.

The soil microbial activity was measured with the fluorescein diacetate (FDA) hydrolysis method [20]. Per soil sample, four 5 g-aliquots of moist soil were analyzed. For wet soil samples, coarse soil particles and clearly visible parts of green manures were removed manually. For dry soil samples, the soil was sieved at a mesh size of $2 \mathrm{~mm}$. All soil samples of one experiment were treated the same way. Five $g$ soil was added to $20 \mathrm{ml}$ of $60 \mathrm{mM}$ potassium phosphate buffer ( $\mathrm{pH} 7.6)$ in a $250 \mathrm{ml}$ Erlenmeyer flask. Three aliquots received $0.2 \mathrm{ml}$ of FDA stock solution ( $2 \mathrm{mg}$ FDA $\mathrm{ml}^{-1}$ acetone), and the fourth aliquot served to determine the background absorbance. Erlenmeyer flasks were placed on a rotary shaker with a controlled temperature set at $90 \mathrm{rpm}$ and $20^{\circ} \mathrm{C}$. The reaction was stopped after 20 min by adding $20 \mathrm{ml}$ acetone. After filtration through Whatman\#1 filter paper, absorbance was measured at $490 \mathrm{~nm}$ with a photo-spectrometer. Soil samples were stored at $4^{\circ} \mathrm{C}$ until analysis for a maximum duration of 4 weeks. Before analysis, the samples were placed at room temperature for $1 \mathrm{~h}$, and the buffer solution was kept at $20^{\circ} \mathrm{C}$ in an incubator to ensure identical conditions for all FDA analyses.

Soil electrical conductivity and soil pH were determined in an air-dried soil: deionized water extract (1:2.5, w:v), the official extraction method in Switzerland. The electrical conductivity was measured with a conductivity meter and soil $\mathrm{pH}$ with a $\mathrm{pH}$ meter.

\subsection{Plant $x$ Soil Experiment}

In a pot trial, two different soil types quite common in Switzerland were mixed with fresh plant material. The two soils naturally infested with $V$. dahliae were Riddes and Epines, loam soil, and sandy loam soil, respectively (Table 2). Plants included in the trial were the two Indian mustard cultivars ISCI-99 and Arid, with a high and a low GSL-content, respectively, and the rye cultivar Wiandi (Table 1). As an additional treatment, the application of biocidal pellets (brand name: Biofence, Triumph Italia, Livorno, Italy) was included in this trial. The pellets are manufactured from partially defatted seed meal of Ethiopian mustard (Brassica carninata A. Braun) and are commercialized as organic fertilizer with a $6 \%$ organic $N$ content [21]. These pellets contain high amounts of GSLS which are transformed to ITCS during the decomposition of the product in the soil [22]. Shredded fresh plants were mixed with the moist soils at a ratio of 9.1:1 and 12.5:1 of moist soil:fresh plant material (v:w) for Indian mustard and rye, respectively. The assumed fresh matter production was $11 \mathrm{~kg} / \mathrm{m}^{2}$ for Indian mustard and 8 $\mathrm{kg} / \mathrm{m}^{2}$ rye. The ratio of moist soil:Biofence pellets was 400:1 (v:w), which corresponds to an amount of $250 \mathrm{~g}$ pellets $/ \mathrm{m}^{2}$. For each plant or pellets $\mathrm{x}$ soil mix, four $640 \mathrm{ml}$ aliquots were placed in a plastic pot with 0.7 liter volume. Pots were watered to the field capacity point, which was determined prior to the experiment as the weight two days after full water saturation, and then placed in a dark incubation room with the temperature ranging from 18.5 to $20.5^{\circ} \mathrm{C}$. For the control treatment, bare soil was processed the same way as the plant or pellet $x$ soil mixtures. After one week of incubation, samples for the determination of the $V$. dahliae population and soil microbial activity were taken. The trial was conducted twice, in May and September 2008.

\subsection{Plant form Experiment}

The efficacy of three different forms of green manure crops, i.e., fresh, dried, and ensilaged plants, to reduce the $V$. dahliae in two different soil types was investigated in a pot trial. The two soils were Conthey and Lamothe, sandy loam and a-clay loam type, respectively (Table 2). The clay loam Lamothe was not naturally infested with $V$. 
dahliae; therefore, the two soils were artificially infested with $V$. dahliae microsclerotia. Four strains of $V$. dahliae were used to produce viable microsclerotia [23]. The strains were strain Aa\#2, isolated from annual wormwood (Artemisia annua L.) [24] strain BDE-572, isolated from eggplant, strain Vd-Michel, isolated from Japanese maple (Acer palmatum Thunb.) [24], and strain BDE-442, isolated from strawberry. Microsclerotia of the four strains with a size between 64 to $125 \mu \mathrm{m}$ were mixed with acid-washed quartz sand and stored in the dark at room temperature until use.

The plants included in the trial were Indian mustard cultivars ISCI-99 and Arid with a high and a low GSLcontent, respectively, rye cultivar Borfuro and sorghum-sudangrass cultivar Susu (Table 1). An additional treatment was the application of the methyl-ITC generating soil fumigant dazomet. For the calculation of the amount of material to be mixed with the soils, the assumption was based on a quantity of fresh matter of $5 \mathrm{~kg} / \mathrm{m}^{2}$ and incorporation depth of $15 \mathrm{~cm}$, i.e., the average depth between a rotavator $(10 \mathrm{~cm})$ and a spading machine $(20 \mathrm{~cm})$. Shredded fresh and ensilaged plants were mixed with the air-dried soils previously sieved at $4 \mathrm{~mm}$ mesh size at a ratio of 30:1 of air-dried soil:fresh plant material $(\mathrm{v}: \mathrm{w})$. As the dry matter content of the dried plants was six times the fresh and ensilaged plants, a ratio of dried plant material:air-dried soil of 180:1 was applied to add the same amount of dry organic matter to the soils. The ratio for dazomet, applied as Basamid (Syngenta, Basel, Switzerland), was 2500:1 (v:w), which corresponds to an amount of $60 \mathrm{~g}$ granules $/ \mathrm{m}^{2}$, the maximum amount authorized in Switzerland. Before adding the plant material or dazomet, the soils were inoculated with $V$. dahliae by mixing $20 \mathrm{~g}$ of microsclerotia/sand mixture with 0.8 liters of soil for $1 \mathrm{~min}$ in a concrete mixer. The 0.8 liters of inoculated soil were then mixed with the corresponding amount of plant material of dazomet for 3 min. For each plant material or dazomet $\mathrm{x}$ inoculated soil mix, four $200 \mathrm{ml}$ aliquots were placed in a plastic pot with 0.25 -liter volume. Pots were watered to the field capacity point by adding 50 or $60 \mathrm{ml}$ of tap water to the pots with soil from Conthey or Lamothe, respectively. Additional $10 \mathrm{ml}$ water was added to the treatments with dried plant material to compensate for the lower quantity of water of this plant material form. For the control treatment, bare soil was processed the same way as the plant or dazomet $x$ soil mixtures. The pots were placed in a dark incubation room with a temperature range from 19 to $20^{\circ} \mathrm{C}$. The weight of each pot was measured at the beginning of the trial, and after one week, water was added to achieve the initial soil moisture status for each pot. After two weeks of incubation, samples were taken to determine the $V$. dahliae population, Streptomyces population, soil microbial activity, soil electrical conductivity, and soil pH. The trial was conducted twice, in April and May 2015.

\subsection{Fumigant Experiment.}

The direct effect of the volatiles generated by the plant material or dazomet was tested in a jar trial. The same amount of shredded fresh ensilaged or dried plant material or dazomet as added to the pots in the plant form experiment was placed on the bottom of a 0.5 -liter glass jar. This quantity was based on the assumption of an average soil porosity of 50\% [25]. Therefore, the pore volume in the pot trial, with 0.8 liters of soil per treatment, corresponding to $400 \mathrm{ml}$, whereas the volume in the jar corresponded to $420 \mathrm{ml}(500 \mathrm{ml}-80 \mathrm{ml}$ occupied by four Petri dishes, see below). Glass jars were equipped with metal clamps and a vulcanized rubber gasket to achieve complete airtightness. A metallic grid was put on the plant material (Fig. 1A), on which four with $V$. dahliae inoculated plastic Petri dishes (5 cm diameter) without lids were placed. Each jar received $2 \times 2$ types of Petri dishes to test the effect on the germination of microsclerotia and on the growth of mycelium. For each of the four replicates, the Petri dishes were placed in a different position of a predefined order (Fig. 1B) to avoid a possible gradient of the volatiles distribution in the jar.

For the germination test, a suspension of $V$. dahliae microsclerotia from strain Aa\#2 in sterile deionized water was sprayed with an airbrush (REVELL 39199, Bünde, Germany) on Petri dishes containing NP-10 medium. The compressor of the airbrush was surface sterilized with $70 \%$ ethanol and placed on a sterile bank to avoid the aspiration of fungal spores suspended in the laboratory's air. Immediately after spraying the microsclerotia suspension, 50 to 60 microsclerotia per petri dish were marked with a green dot on the bottom of the dish (Fig. 2). The mycelium growth test was effectuated with strain Aa\#2 grown on PDA (potato dextrose agar) medium in the dark at $24^{\circ} \mathrm{C}$. From an actively growing colony, a $6 \mathrm{~mm}$ diameter agar plug was taken and placed in the middle of a PDA containing a Petri dish (Fig. 2). After placing the four Petri dishes in the jar, $55 \mathrm{ml}$ of tap water was added to cover the material on the bottom. The jar was then closed hermetically to avoid any losses of the volatiles formed 
by the materials. The jars were incubated in the dark at $19^{\circ} \mathrm{C}$ for $24 \mathrm{~h}$. The Petri dishes were then removed from the jar, the lid was added, and they were incubated in the dark at $24^{\circ} \mathrm{C}$. After one and two weeks of incubation, the percentage of germination and the mycelium diameter were assessed for the germination and growth test, respectively. The trial was conducted twice, in March and April 2015.

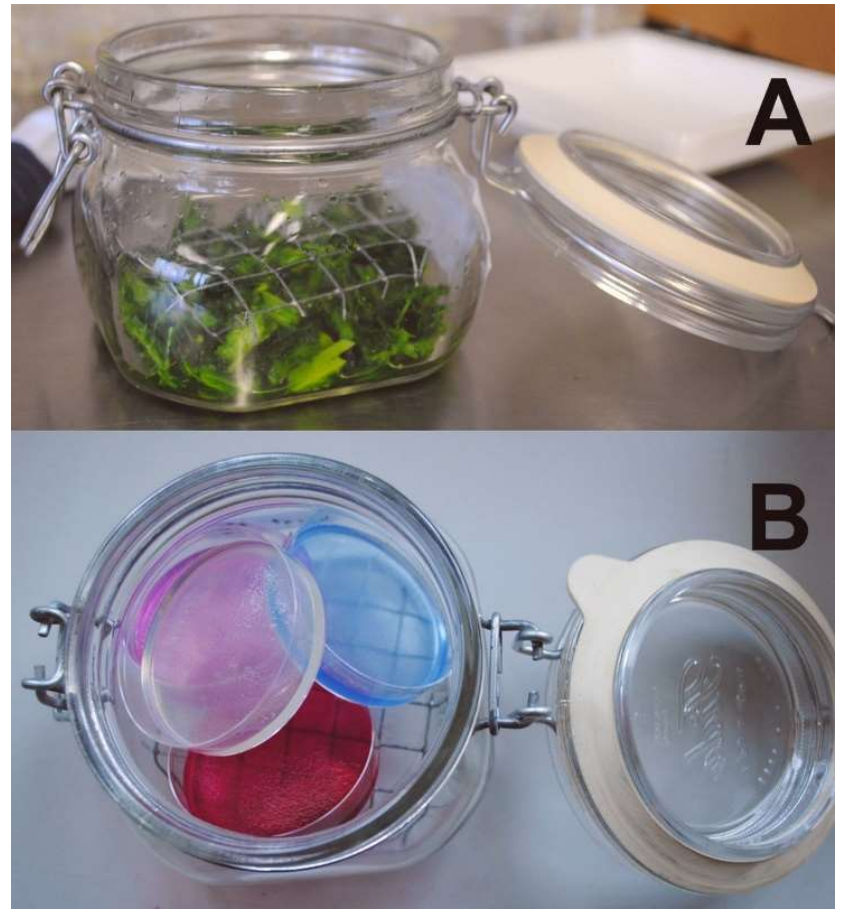

Figure 1: A glass jar with 0.5-liter volume is equipped with metal clamps and a vulcanized rubber gasket containing a metallic grid placed over shredded fresh plant material (A). Petri dishes $(5 \mathrm{~cm}$ diameter) were placed in different positions of a predefined order (B), indicated by different colored agar (for demonstration purposes only).

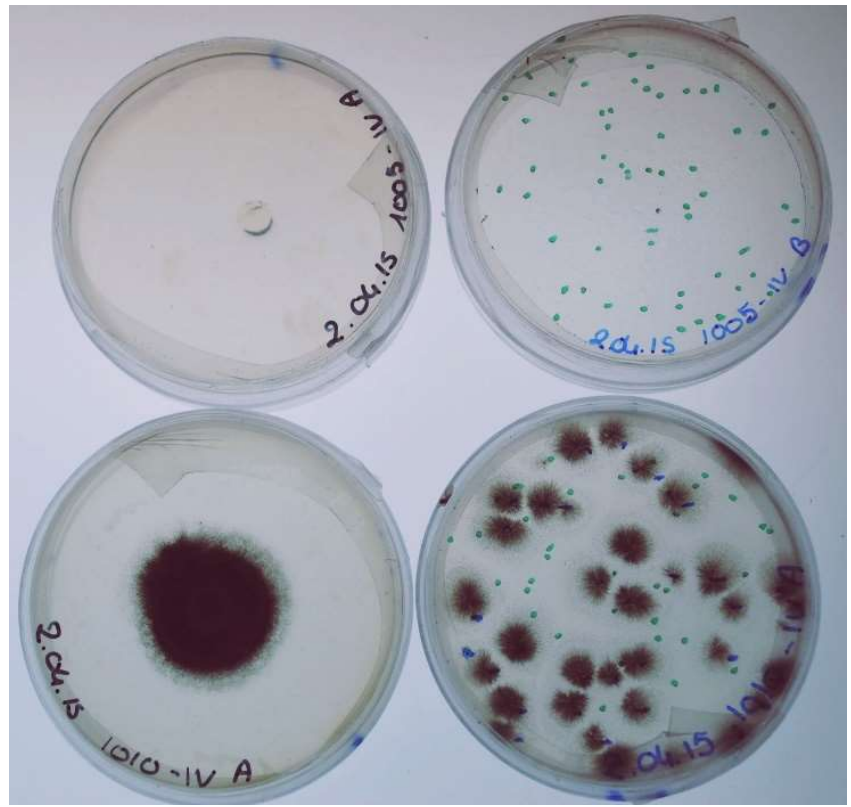

Figure 2: Petri dishes (5 $\mathrm{cm}$ diameter) for mycelium growth test on PDA medium (left side) and microsclerotia germination test on NP-10 medium (right side) of Verticillium dahliae. Efficacy was assessed by measuring mycelium diameter or counting the number of germinated microsclerotia. Latter ones were marked with a green dot immediately after their deposition on the agar. The top treatment with high efficacy is Indian mustard ISCI-99 in dry form, the bottom treatment with a low efficacy is Indian mustard Arid in ensilaged form, both after two weeks of incubation at $24^{\circ} \mathrm{C}$. 


\subsection{Data Analysis}

For the plant $x$ soil and the plant form experiments, the number of living $V$. dahliae microsclerotia in the soil was transformed into a relative number of microsclerotia with the control treatment set to the value of 1 . For this transformation, which allows a better comparison of the soil effect than the absolute number of living microsclerotia, the average value of the control treatments calculated for each trial separately was set to 1 , thereby maintaining the variance in the control treatment. For the fumigant experience, non-transformed data of the number of living microsclerotia were used for statistical analysis.

Data were analyzed using SigmaPlot 13 (Systat Software, Inc., San Jose, CA). Analysis of variance (ANOVA) was used for all trials, and in cases of significant differences at $P<0.05$, multiple comparisons were run using the Tukey test. In the plant $x$ soil experiment and the plant form experiment, the influence of the soil parameters on the relative number of living microsclerotia was analyzed with linear or stepwise regression analysis.

\section{Results}

\subsection{Plant $x$ Soil Experiment}

Adding green manures and biocidal pellets to the two soils Epines and Riddes, resulted in significantly different numbers of living $V$. dahliae microsclerotia $(P<0.001)$. All three green manures resulted in a significant reduction of living microsclerotia in both soils, whereas the effect of the biocidal pellets was not significantly different from the control (Fig. 3A). However, the efficacy of the treatments was strongly influenced by the soil type (interaction treatments $x$ soil: $P<0.001)$. In the sandy loam soil Riddes, the Indian mustard cultivars significantly reduced the

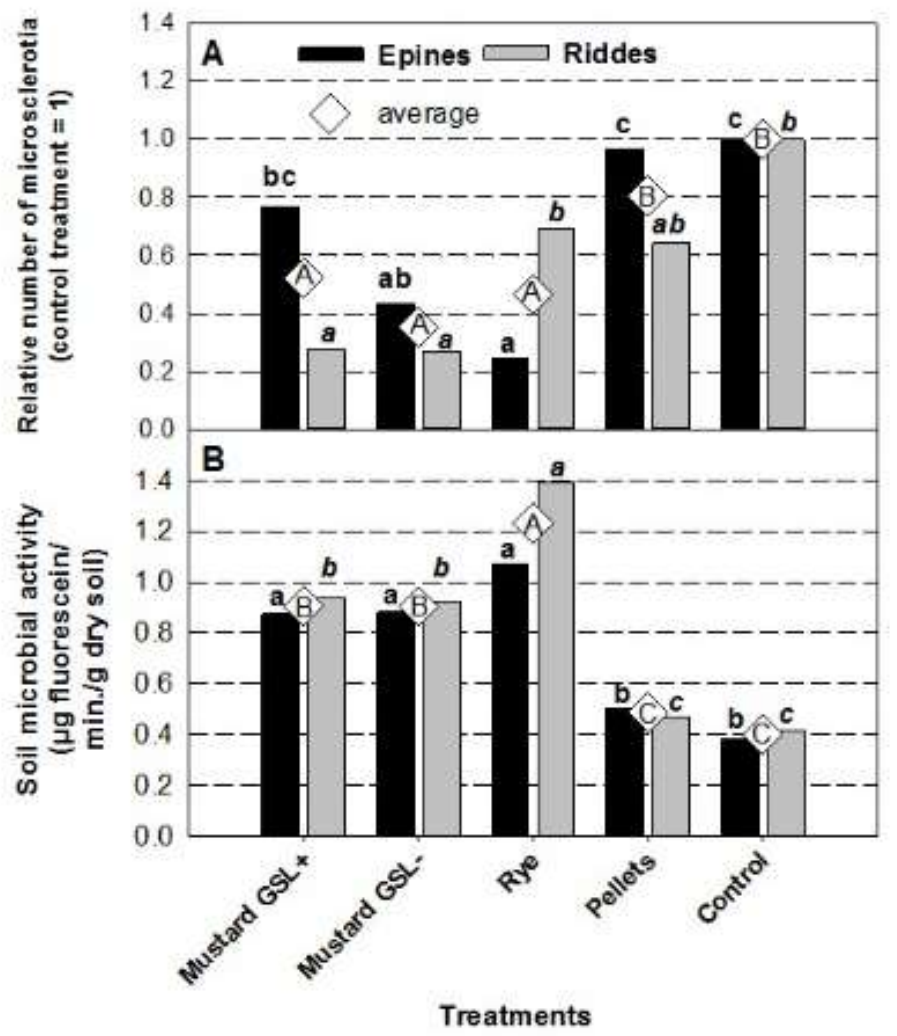

Figure 3: The relative number of living Verticillium dahliae microsclerotia (A) and soil microbial activity (B) of Indian mustard with a high glucosinolate content (GSL+, cv. ISCI-99) and a low glucosinolate content (GSL-, cv Arid), rye cultivar Wiandi, and biocidal Biofence pellets in the sandy loam soil Epines and the loam soil Riddes. Treatments with different letters are significantly different (Tukey-test, $P=5 \%$ ). Upper-case letters concern average values over both soils, lower-case normal letters soil Epines, lower-case italic letters soil Riddes. Data presented are the means of two trials. 
number of living $V$. dahliae microsclerotia independently from their GSL content. However, rye as non-Brassica species did not significantly reduce the number of microsclerotia compared to the control. In contrast, in the sandy soil, Epines, rye, and the low GSL-content Indian mustard cultivar Arid significantly reduced the number of living V. dahliae microsclerotia. In contrast, the high GSL-content mustard ISCI-99 and the biocidal pellets were not significantly different from the control. The green manures significantly increased the microbial activity compared to the pellets and the control $(P<0.001)$. Rye had a more substantial effect than the two Indian mustard cultivars (Fig. 3B).

The soil microbial activity was positively correlated with the efficacy to reduce the number of $V$. dahliae microsclerotia (Table 3). Over both soils, the microbial activity explained a 26\% (adjusted $r^{2}$-value) reduction in the number of living microsclerotia. In the sandy soil Epines, the effect of the soil microbial activity was more important with $36 \%$ than in the sandy loam soil Riddes with $18 \%$.

Table 3: Linear regression between soil microbial activity (sma) as independent factor, and relative number of $v$. dahliae microsclerotia (rel_Vd_MS) as dependent factor of the plant $x$ soil experiment. Data from both trials were bulked for analysis.

\begin{tabular}{|c|c|c|c|}
\hline & Equation & number & adj. $\mathbf{r}^{2}$-value \\
\hline \hline Both soils & rel_Vd_MS $=109.8-\left(59.7^{*}\right.$ Sma $)$ & 80 & 0.263 \\
\hline Epines & rel_Vd_MS $=128.2-\left(80.7^{*}\right.$ Sma $)$ & 40 & 0.358 \\
\hline Riddes & rel_Vd_MS $=95.8-\left(46.3^{*}\right.$ sma $)$ & 40 & 0.001 \\
\hline
\end{tabular}

\subsection{Fumigant Experiment}

The effect of the volatiles released by the different forms of green manure plants was highly significant on both the microsclerotia germination and the mycelium growth after 7 days $(P<0.001)$ and 14 days $(P<0.001)$. The Indian mustard cultivar ISCl-99 in the dried form completely reduced microsclerotia germination and mycelium growth even after 14 days (Fig. 4). As a fresh plant, ISCl-99 reduced by $90 \%$ the microsclerotia germination and by more than $70 \%$ the mycelium growth 14 days after treatment. The dry form of the sorghum-sudangrass and, less pronounced, of the Indian mustard cultivar Arid significantly reduced the microsclerotia germination 7 days after treatment, but not after 14 days. Both treatments did not affect mycelium growth. On both dates, the soil fumigant dazomet had a significantly higher effect on the microsclerotia germination but not on mycelium growth than the control treatment. All other treatments were not significantly different from the control.

\subsection{Plant form Experiment}

The treatments resulted in significant differences for the parameters relative number of living $V$. dahliae microsclerotia, soil microbial activity, soil electrical conductivity, and Streptomyces population (all at $P<0.001$ ), only the soil $\mathrm{pH}$ was not influenced. The soil type had a significant effect on parameters relative number of living $V$. dahliae microsclerotia, soil microbial activity, soil electrical conductivity, soil pH (all at $P<0.001$ ), and Streptomyces population $(P=0.002)$. Interactions between treatments and soil type occurred for the parameters relative number of living $V$. dahliae microsclerotia $(P=0.017)$ and soil microbial activity $(P<0.001)$. The average reduction or the relative number of living $V$. dahliae microsclerotia was $26.5 \%$ and $61.4 \%$ in the soil Conthey and Lamothe, respectively. The higher effect in soil Lamothe was expressed by a significant reduction of the microsclerotia by all treatments with the exception of the fresh form of the Indian mustard cultivars Arid and ISCI-99 (Fig. 5A).

In contrast, in soil Conthey, only ensilaged rye and dazomet significantly affected the number of living microsclerotia. The soil microbial activity was significantly decreased in both soils by the fumigant dazomet (Fig. 5B). In contrast, all green manures except fresh sorghum-sudangrass significantly increased the microbial activity in soil Conthey. In soil Lamothe, where the soil microbial activity in control was $83 \%$ higher than in soil Conthey, the influence of the plant material was less pronounced; 7 out of 12 treatments had a significant effect. The 
treatments did not affect the soil $\mathrm{pH}$ and only slightly affected electrical conductivity (data not shown). For the latter parameter, only dried rye did increase the electric conductivity significantly compared to the control. The Streptomyces population was significantly increased, mainly by the ensilaged form of the green manures, i.e., the Indian mustard cultivar Arid, rye, and sorghum-sudangrass silage (Fig. 5C). The two other treatments with a significantly positive effect on Streptomyces were the dried Indian mustard cultivar ISCI-99 and dried rye. No effect of the fumigant dazomet on the Streptomyces population was measured. The two parameters, soil $\mathrm{pH}$ and Streptomyces population, explain 18\% (adjusted $r^{2}$-value) of the efficacy of the treatments (Table 4). When dazomet, which knowingly acts by the generation of the toxic volatile molecule methyl-ITC, was excluded from the backward stepwise regression analysis, the soil microbial activity was the third parameter to explain the efficacy, with 32\% of the effect explained by a combination of the three parameters soil microbial activity, soil pH and Streptomycespopulation.

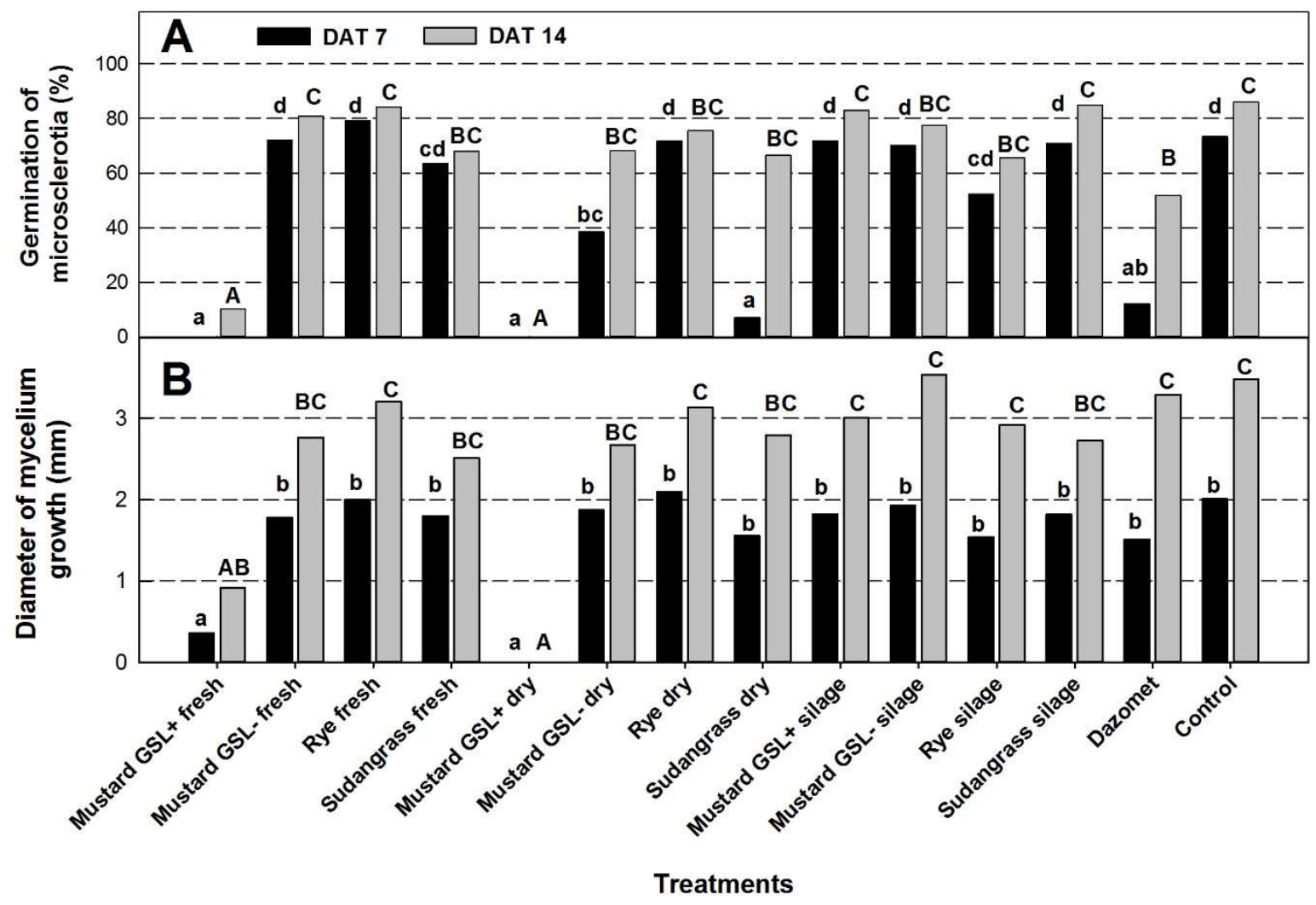

Figure 4: Effect on the germination of microsclerotia (A) and the mycelium growth (B) of volatiles, which are generated by Indian mustard with a high glucosinolate content (GSL+, CV. ISCl-99) and a low glucosinolate content (GSL-, cv Arid), rye (cv. Borfuro, sorghum-sudangrass (cv. Susu), and the soil fumigant dazomet (product Basamid). The plants were applied in fresh, dried, and ensilaged form. Data were assessed 7 and 14 days after treatment started (DAT). Treatments with different letters are significantly different (Tukey-test, $P=5 \%$ ). Lower-case letters concern DAT 7, upper-case letters DAT 14. Data presented are the means of two trials.

\section{Discussion}

One of the prerequisites for a successful application of biofumigation is the incorporation of a sufficient amount of GSLs in the soil to generate a level of ITCs high enough to kill the inoculum of soilborne pathogens [6]. Therefore, the use of cultivars with a high GSL-content is recommended [11, 26]. The biofumigation effect of reducing the number of living $V$. dahliae microsclerotia was partially demonstrated in the plant $\mathrm{x}$ soil experiment. In the loam soil Riddes, no significant difference between the two Indian mustard cultivars ISCI-99 with a high and Arid with a low GSL-content occurred, but both were more efficient than rye. In contrast, in the sandy loam soil Epines, the efficacy of the Indian mustard cultivar ISCI-99 with a high GSL-content was significantly lower than the efficacy of rye and not significantly different from the untreated control. The two soils have very similar organic 
matter contents and $\mathrm{pH}$ values but a quite different soil texture, mainly concerning the percentage of sand and silt. The lower effect of the high GSL-content Indian mustard ISCI-99 and the biofumigation pellets in the soil Epines might result from the more coarse texture of this sandy loam ( $75 \%$ sand, $6 \%$ clay). In soils with a high fraction of sand and a low fraction of clay, water retention is lower and larger pores are rapidly filled with air [27]. Such a situation increases the risks of ITC-losses by volatilization or leaching [5] Studies on the influence of the soil type on the efficacy of aliphatic ITCS, such as 2-propenyl ITC generated by sinigrin, the major GSL in Indian mustard cultivars [28] showed in the first line the negative correlation between soil organic matter content and biological activity of 2-propenyl ITC [11, 13].

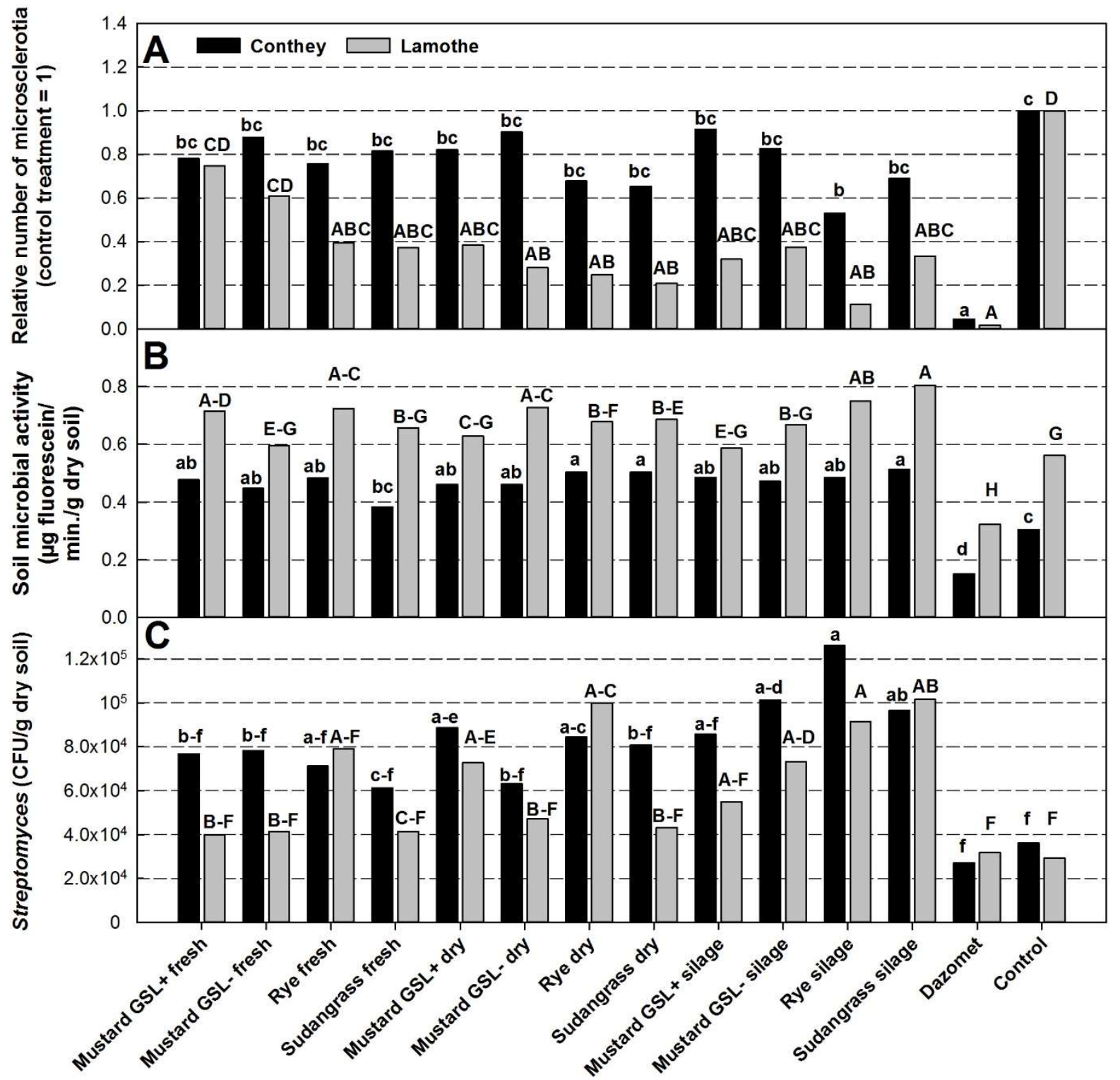

Treatments

Figure 5: Effect on the relative number of living $V$. dahliae microsclerotia (A), on the soil microbial activity (B), and the soil Streptomyces populations (C) of Indian mustard with a high glucosinolate content (GSL+, CV. ISCI-99) and a low glucosinolate content (GSL-, cv Arid), rye (cv. Borfuro, sorghum-sudangrass (cv. Susu), and the soil fumigant dazomet (product Basamid) in the sandy loam soil (Conthey) and the clay loam soil (Lamothe). The plants were applied in fresh, dried, and ensilaged form. The parameters were measured 14 days after plant material and dazomet were added to the soils. For all three parameters, significant differences between the two soils existed. Treatments with different letters are significantly different (Tukey-test, $P=$ 5\%). Lower-case letters concern soil Conthey, upper-case letters soil Lamothe. Data presented are the means of two trials. 
Table 4: Multiple linear regression of the plant form experiment based on a backward stepwise regression analysis including soil microbial activity (sma), soil $\mathrm{pH}(\mathrm{pH})$, electrical conductivity (EC), absolute Streptomyces population (Str.) and log10 Streptomyces population (log Str.) as independent factors and relative number of V. dahliae microsclerotia (rel_Vd_MS) as dependent factor. Data from both trials were bulked for analysis.

\begin{tabular}{|c|c|c|c|}
\hline Equation & $\mathbf{n}$ & adj. $\mathbf{r}^{2}$-value & P-value \\
\hline \hline With dazomet & & & $<0.001$ \\
\hline rel_Vd_MS dazomet $=2.15+\left(0.39^{*} \mathrm{pH}\right)-(0.00000137 *$ Str. $)$ & 224 & 0.182 & \\
\hline Without dazomet & & & $<0.001$ \\
\hline rel_Vd_MS $=1.31-\left(0.58^{*}\right.$ sma $)+\left(0.333^{*} \mathrm{pH}\right)-(0.00000192 *$ Str. $)$ & 208 & 0.322 & $<$ \\
\hline
\end{tabular}

Additionally to the organic matter, an influence of the soil type was reported to be responsible for reducing the lethal effect of 2-propenyl ITC on white-fringed weevil (Naupactus leucoloma) larvae [11]. The efficacy was slightly higher, i. e., lower $L_{95}$ concentration, with sandy soil compared to loamy soil. However, the insect larvae were not exposed to the ITC in but above the soil, i.e., in the headspace of the flask in which the soil was placed. In such a case, the higher efficacy over a sandy soil means more ITC accumulated in the headspace, which means that more ITC losses occurred from the sandy soil, which would fit with the lower efficacy in the sandy loam soil in the plant $x$ soil experiment. No suppression on $V$. dahliae microsclerotia with biofumigation was reported from a field trial in soil with a very high sand fraction (94.9\%). In this soil, the incorporation of a $B$. juncea green manure supplemented with a high amount of broccoli (Brassica oleracea L.) and also the chemical fumigation with metamsodium resulted in no difference compared to the non-amended control treatment, whereas adding a large amount of chitin reduced the number of microsclerotia [29] significantly.

Adding easily degradable organic matter in the form of fresh green manure plants strongly stimulated in both soils of the plant $x$ soil experiment the soil microbial activity, which is the major factor causing soil fungistasis [8]. Soil microbial activity expressed as FDA hydrolysis was associated with lower development of Verticillium wilt of potatoes, which was reduced by incorporating three green manures [30]. Among a series of microbiological, chemical, and enzymatic parameters, FDA hydrolysis was one of the most valuable features to identify the suppressiveness of organic amendments [31]. In the plant $x$ soil experiment, the soil microbial activity expressed as FDA hydrolysis explained by $36 \%$ the effect of the organic amendments to reduce the number of $V$. dahliae microsclerotia in the sandy loam soil Epines, and to a lower extent of $20 \%$ in the loamy soil Riddes. This difference might be explained by a stronger effect of the volatiles generated by the high GSL-content Indian mustard ISCI-99 in the loamy soil Riddes. The 2-propenyl ITC generated by ISCI-99 is not only toxic to $V$. dahliae, but was also reported to affect negatively beneficial microorganisms such as ammonium and nitrite-oxidizing bacteria [32]. ITCs have unspecific toxicity [33], which could explain the lower importance of the soil microbial activity on the efficacy in the soil Riddes where ISCI-99 had the highest efficacy.

In both soils, incorporating fresh green manures increased soil microbial activity compared to non-amended soil. The incorporation of fresh Indian mustard plants was reported to increase the soil bacterial and fungal densities [34]. The increase of the bacterial density caused by the mustard incorporation was exceptionally high one week after incorporation. After the incorporation of a mixture of fresh wooly pod vetch (Vicia dasycarpa Ten.) and oats (Avena sativa L.), the soil microbial activity was increased compared to the non-amended control, with again the strongest FDA activity one week after incorporation [35]. In both studies, the increase of the microbial activity had no longer-lasting effect on the aimed pathogens Rhizoctonia solani, Fusarium oxysporum, and Pythium aphanidermatum, which might be caused by their high saprophytic capabilities to survive on the decomposing green manure material [31]. In contrast, $V$. dahliae, with very low saprophytic capacities [1], makes this pathogen more vulnerable to control methods based on the amendment of the soil with easily degradable organic matter. Incorporating sudangrass (Sorghum vulgare var. sudanese) or corn (Zea mays L.) resulted in a strongly reduced Verticillium wilt incidence and an increased yield of potato [36].

Another specific group of soil microorganisms stimulated by the incorporation of several green manure crops are Streptomyces [9]. Species of this genus are antagonistic to $V$. dahliae [37]. The antagonistic effect of 
Streptomyces is based on their production of a range of enzymes capable of degrading the cell wall of fungal pathogens and on the production of antifungal compounds [38]. The production of antibiotics by Streptomyces is influenced by the carbon compounds used as a substrate of these saprophytic bacteria [39]. Organic amendments such as rapeseed seed meal are suited for the production of antibiotics by Streptomyces thermoviolaceus [40] and increase the Streptomyces densities in the soil [41]. In the plant form experiment, the Streptomyces population was positively correlated to the efficacy in reducing the number of $V$. dahliae microsclerotia. Among the three forms of green manures, silage resulted in the highest number of Streptomyces in the soil. Rye silage with the highest Streptomyces population was the only green manure treatment with a significant efficacy against $V$. dahliae in the soil Conthey. During the silage process, sugars are transformed into lactic acid under anaerobic conditions by lactic acid bacteria naturally occurring on the ensilaged plant material [42]. This process increases the digestibility of green plants for ruminants, and, as the first step of the digestion system of ruminants is based on microbial fermentation, it most probably also stimulates the growth of soil microorganisms. Next to an increase in the number of Streptomyces, the ensilaged forms might also have affected the production of antifungal compounds. The ability to inhibit the growth of Pythium ultimum and Rhizoctonia solani by a strain of Streptomyces lydicus was influenced by different sugars [43]. A high nutrient input also results in a more inhibitory Streptomyces community [39], which might help to explain the highest efficacy of silage as a form in which green manures were applied.

In contrast, the fumigant experiment clearly showed that the generation of toxic volatile molecules was not part of the suppressiveness of the ensilaged green manures. The very high effect of the volatiles released by the high GSL-content Indian mustard ISCI-99 in fresh and dried form was entirely canceled by the ensilage process of the same cultivar. One consequence of this process is a pH between 4.2 and 5.0 of the silages used in the fumigant and plant form experiments. The $\mathrm{pH}$ value influences the outcome of the GSL hydrolysis of the Brassica tissues [33]. At a low pH, non-volatile nitriles are generated in place of volatile ITCs. Drying as the other conservation form did not affect the efficacy of the volatiles released by the green manures. With a drying method similar to the one used in our experiments, GSL contents of different cruciferous species were reduced by less than 40\%, and myrosinase activity was maintained at a sufficient level [22]. The dried form of the high GSL Indian mustard ISCI-99 had a more consistent efficacy compared to the fresh form. Dry low GSL Indian mustard Arid and sorghum-sudangrass had even a significantly higher efficacy against $V$. dahliae microsclerotia one week after application than their fresh form. A possible reason for the increased efficacy of the dry form might be the finer shredding grade of the dried plant material and no losses of volatiles during the shredding process, which eventually occurred for the fresh plants.

The low efficacy of dazomet in the fumigant experiment was in complete contrast to the very high efficacy of this chemical substance in both soils in the plant form experiment. This was explained by an additional fumigant experiment, in which one $g$ of a soil mixture from Conthey and Lamothe was added to the dazomet before water was applied. This favored the hydrolysis of the dazomet to methyl ITC and resulted in a 100\% efficacy to inhibit $V$. dahliae microsclerotia germination and mycelium growth (data not shown).

Our experiments included rye as non-biofumigant green manure, i.e., a plant species not releasing toxic volatiles. However, a small effect of volatiles generated by macerated rye plants on the growth of Rhizoctonia solani and Pythium ultimum was reported by [44]. But the initial suppressive effect of rye was not lasting, similar to results of the fumigant experiment, where after one week, no effect of rye on the microsclerotia and mycelium of V. dahliae occurred.

The effect of the toxic volatiles generated by the high GSL Indian mustard ISCI-99 in fresh or dried form appeared ineffective when the plant material was mixed with the soils. In the clay loam soil Lamothe, where nearly all treatments had a significant efficacy, fresh ISCI-99 resulted in the lowest efficacy, which was not significantly different from the control. Neubauer et al. [13] reported that the 2-propenyl ITC released by $B$. juncea reduced the number of living microsclerotia from 69 to $81 \%$ when the plant material was added to sterile quartz sand, but in naturally infected soil, the reduction was only 10 to $66 \%$, which was considered as an insufficient level of control. Two factors were considered responsible for this lower efficacy: organic matter content of the soils [42, 13] and microbial degradation of the ITC [45-46]. The latter factor was probably not important in the plant form experience, as both soils used were not treated with ITC generating plants or products before they were collected. 
But the organic matter content of the two soils Conthey and Lamothe, of 2.3 and $2.4 \%$, respectively, were both above the organic carbon content of $1 \%$ (which corresponds to $1.75 \%$ organic matter) considered as critical for a successful application of biofumigation [13].

In the plant form experiment, the efficacy of the green manures was strongly affected by the soil type, as this was clearly demonstrated with one and ten treatments significantly different from the control in the soil Conthey and Lamothe, respectively. The mechanisms of suppressiveness to a specific soilborne pathogen can be quite different between soils and be based on different biological factors, such as mycoparasitism by fungi or antibiosis by actinomycetes [47]. But also, the composition of a specific group of soil microorganisms can be influenced by the soil type. The soil type more strongly influenced the diversity of fluorescent pseudomonads than the plant species cultivated on the soils [48]. The bacterial diversity in six soils was most influenced by the $\mathrm{pH}$ [49], and $\mathrm{pH}$ is considered as the main factor influencing bacterial community structures on a worldwide scale [50]. In the plant form experiment, the two soils had, next to a different soil texture, a pH value difference of 1.2. In this experiment, the efficacy in reducing the number of $V$. dahliae microsclerotia was negatively correlated to the $\mathrm{pH}$ value. Therefore, the lower $\mathrm{pH}$ of the soil Lamothe was most probably an important factor that caused the lower survival ability of $V$. dahliae microsclerotia in this soil. The other factor, the Streptomyces population, was positively correlated to reducing the $V$. dahliae population in the plant form experiment.

In contrast to soil pH can the size and/or composition of the soil Streptomyces populations be influenced by the addition of organic amendments $[9,51]$. This aspect has to be taken into account for the application of organic amendments, especially when the soil health status is the priority [52]. Ensilaged green manures are especially well suited for this purpose. Not only have they a positive effect on the Streptomyces populations, but also are their application time and site-independent. This is a key factor for their use on prime horticultural soils, especially for greenhouse or peri-urban production sites. Applying green manures on a different site from where it was produced also avoids the multiplication effect on soilborne pathogens through the green manure crop [53].

The production and storage of dried or ensilaged green manures, however, causes additional costs. The economic aspects of the use of green manures have to be considered, and not always the most efficient treatment is also the most profitable [54]. The economic advantages of green manures concern not only the soil health status. Green manures can also improve the water infiltration rate [55] or reduce nitrate leaching [10]. The choice of biocidal vs. non-biocidal is an important question as the toxic molecules released by biocidal green manures are non-specific and can also affect beneficial soil organisms [56]. On the other hand, could the delayed $\mathrm{N}$ mineralization after incorporating biocidal Brassicaceae [57] be advantageous when substantial amounts of green manures are incorporated. Therefore, the decision of which kind and which form of green manures to apply depends on multiple factors that are different for each specific grower's situation.

\section{Conclusion}

In conclusion, the effect of green manure crops to reduce the number of $V$. dahliae microsclerotia is influenced by the soil texture, plant species, and conservation form. Biofumigant green manures such as Indian mustard with a high GSL content can be used in soils with a low sand fraction in fresh or dried form, but not as silage. In contrast, non-biocidal green manures are less influenced by soil texture. Next to their stimulation of the general soil microbial activity, they increase the soil Streptomyces populations, especially when applied in ensilaged form.

\section{Acknowledgments}

We thank H. Ahmed, R. Ançay, and S. Dahal for their technical assistance and C. Baroffio and C. Carlen for their helpful comments.

\section{References}

[1] Pegg GF, Brady BL. Verticillium wilts. CABI Publishing, Wallingford, UK. 2002. https://doi.org/10.1079/9780851995298.0000

[2] Farr DF, Rossman AY. Fungal Databases. Systematic Mycology and Microbiology Laboratory, ARS, USDA. Retrieved 25 November 2016, from http://nt.ars-grin.gov/fungaldatabases/. 2016. 
[3] Gullino ML, Camponogara A, Gasparrini G, Rizzo V, Clini C, Garibaldi A. Replacing methyl bromide for soil disinfestation: the Italian experience and implications for other countries. Plant Dis. 2003; 97: 1012-1021. https://doi.org/10.1094/PDIS.2003.87.9.1012

[4] Larkin RP. Green manures and plant disease management. CAB Reviews 2013; 8(037): Online publication. https://doi.org/10.1079/PAVSNNR20138037

[5] Morris EK, Fletcher R, Veresoglou SD. Effective methods of biofumigation: a meta-analysis. Plant Soil 2020; 446: $379-392$. https://doi.org/10.1007/s11104-019-04352-y

[6] Kirkegaard J. Biofumigation for plant disease control - from the fundamentals to the farming system. In: Walters, D. (ed.). Disease control in crops: Biological and environmentally friendly approaches. Wiley-Blackwell, Oxford, UK. 2009.

[7] de Nicola GR, Leoni O, Malaguti L, Bernardi R, Lazzeri L. A simple analytical method for dhurrin content evaluation in cyanogenic plants for their utilization in fodder and biofumigation. J. Agric. Food Chem. 2011; 59: 8065-8069. https://doi.org/10.1021/jf200754f

[8] Garbeva P, Hol WHG, Termorshuizen AJ, KowalchukGA, de Boer W. Fungistasis and general soil biostasis - A new synthesis. Soil Biol. Biochem. 2011; 43: 469-477. https://doi.org/10.1016/j.soilbio.2010.11.020

[9] Wiggins BE, Kinkel LL. Green manures and crop sequences influence potato diseases and pathogen inhibitory activity of indigenous Streptomycetes. Phytopathology 2005; 95: 178-185. https://doi.org/10.1094/PHYTO-95-0178

[10] Kristensen HL, Thorup-Kristensen K. Root growth and nitrate uptake of three different catch crops in deep soil layers. Soil Sci. Soc. Am. J. 2004; 68: 529-537. https://doi.org/10.2136/sssaj2004.5290

[11] Matthiessen JN, Shackleton MA. Biofumigation: environmental impacts on the biological activity of diverse pure and plant-derived isothiocyanates. Pest Manag. Sci. 2005; 61: 1043-1051. https://doi.org/10.1002/ps.1086

[12] Michel W, Mew TW. Effect of a soil amendment on the survival of Ralstonia solanacearum in different soils. Phytopathology 1998; 88: 300-305. https://doi.org/10.1094/PHYTO.1998.88.4.300

[13] Neubauer C, Heitmann B, Müller C. Biofumigation potential of Brassiceae cultivars to Verticillium dahliae. Eur. J. Plant Pathol. 2014; 140: 341-352. https://doi.org/10.1007/s10658-014-0467-9

[14] Harris DC, Yang JR. The relationship between the amount of Verticillium dahliae in soil and the incidence of strawberry wilt as a basis for disease risk prediction. Plant Path. 1996; 45: 106-114. https://doi.org/10.1046/j.1365-3059.1996.d01-96.x

[15] Subbarao KV, Kabir Z, Martin FN, Koike ST. Management of soilborne disease in strawberry using vegetable rotations. Plant Dis. 2007; 91: 964-972. https://doi.org/10.1094/PDIS-91-8-0964

[16] Falk KL, Tokuhisa JG, Gershenzon J. The effect of sulfur nutrition on plant glucosinolate content: Physiology and molecular mechanisms. Plant Biol. 2007; 9: 573-581. https://doi.org/10.1055/s-2007-965431

[17] Butterfield EJ, DeVay JE. Reassessment of soil assays for Verticillium dahliae. Phytopathology 1977; 67: $1073-1078$.

[18] Kabir Z, Bhat RG, Subbarao KV. Comparison of media for recovery of Verticillium dahliae from soil. Plant Dis. 2004 ; 88 : $49-55$. https://doi.org/10.1094/PDIS.2004.88.1.49

[19] Dhingra OD, Sinclair JB. Basic plant pathology methods, $2^{\text {nd }}$ Ed. CRC Press, Boca Raton, FL, USA. 1995.

[20] Schnürer J, Rosswall T. Fluorescein diacetate hydrolysis as a measure of total microbial activity. Appl. Environ. Microbiol. 1982; 43: 12561261. https://doi.org/10.1128/aem.43.6.1256-1261.1982

[21] Patalano G. New practical perspectives for vegetable biocidal molecules in Italian agriculture, Bluformula brand for commercialisation of biocidal green manure and meal formulations. Agroindustria 2004; 3: 409-412.

[22] Lazzeri L, Leoni O, Manici LM. Biocidal plant dried pellets for biofumigation. Industrial Crops Prod. 2004; 20 : 59-65. https://doi.org/10.1016/j.indcrop.2003.12.018

[23] Hawke MA, Lazarovits G. Production and manipulation of individual microsclerotia of Verticillium dahliae for use in studies of survival. Phytopathology 1994; 84: 883-890.

[24] Michel VV, Dessimoz M, Simonnet X. First Report of Verticillium dahliae causing wilt on annual wormwood in Switzerland. Plant Dis. 2016; 100: 1235. https://doi.org/10.1094/PDIS-09-15-0971-PDN

[25] Eash NS, Green CJ, Razvi A, Bennett WF. Soil science simplified, 5 th Ed. Blackwell Publishing, Ames, IA, USA. 2008.

[26] Mayton HS, Olivier C, Vaughn SF, Loria R. Correlation of fungicidal activity of Brassica species with allyl isothiocyanate production in macerated leaf tissue. Phytopathology 1996; 86: 267-271.

[27] Hillel D. Soil and water: Physical principles and processes. Academic Press, New York, NY, USA. 1971.

[28] Kirkegaard J, Sarwar M. Biofumigation potential of brassicas I. Variation in glucosinolate profiles of diverse field-grown brassicas. Plant Soil 1998; 201: 71-89. https://doi.org/10.1023/A:1004364713152

[29] Korthals GW, Thoden TC, van den Berg W, Visser JHM. Long-term effects of eight soil health treatments to control plant-parasitic nematodes and Verticillium dahliae in agro-ecosystems. Appl. Soil Ecol. 2014; 76: 112-123. https://doi.org/10.1016/j.apsoil.2013.12.016

[30] Ochiai N, Powelson ML, Crowe FJ, Dick RP. Green manure effects on soil quality in relation to suppression of Verticillium wilt of potatoes. Biol. Fertil. Soils 2008; 44: 1013-1023. https://doi.org/10.1007/s00374-008-0289-z

[31] Bonanomi G, Antignani V, Capodilupo M, Scala F. Identifying the characteristics of organic soil amendments that suppress soilborne plant diseases. Soil Biol. Biochem. 2010; 42: 136-144. https://doi.org/10.1016/j.soilbio.2009.10.012 
[32] Bending GD, Lincoln SD. Inhibition of soil nitrifying bacteria communities and their activities by glucosinolate hydrolysis products. Soil Biol. Biochem. 2000; 32: 1261-1269.

[33] Brown PD, Morra MJ. Control of soilborne plant pests using glucosinolate-containing plants. Adv. Agron. 1997; 61: $167-231$. https://doi.org/10.1016/S0065-2113(08)60664-1

[34] Friberg H, Edel-Hermann V, Faivre C, Gautheron N, Fayolle L, Faloya V, et al. Cause and duration of mustard incorporation effects on soilborne plant pathogenic fungi. Soil Biol. Biochem. 2009; 41: 2075-2084. https://doi.org/10.1016/j.soilbio.2009.07.017

[35] Grünwald NJ, Hu S, van Bruggen AHC. Short-term cover crop decomposition inorganic and conventional soils: Characterization of soil C, N, microbial and plant pathogen dynamics. Eur. J. Plant Pathol. 2000; 106: 37-50. https://doi.org/10.1023/A:1008720731062

[36] Davis JR, Huisman OC, Westermann DT, Hafez SL, Everson DO, Sorensen LH, et al. Effects of green manures on Verticillium wilt of potato. Phytopathology 1996; 86: 444-453.

[37] Bubici G, Marsico AD, D’Amico M, Amenduni M, Cirulli M. Evaluation of Streptomyces spp. for the biological control of corky root of tomato and Verticillium wilt of eggplant. Appl. Soil Ecol. 2013; 72: 128-134. https://doi.org/10.1016/j.apsoil.2013.07.001

[38] Faheem M, Raza W, Zhong W, Nan Z, Shen Q, Xu Y. Evaluation of the biocontrol potential of Streptomyces goshikiensis YCXU against Fusarium oxysporum f. sp. niveum. Biol. Control 2015; 81: 101-110. https://doi.org/10.1016/j.biocontrol.2014.11.012

[39] Schlatter D, Fubuh A, Xiao K, Hernandez D, Hobbie S, Kinkel L. Resource amendments influence density and competitive phenotypes of Streptomyces in soil. Microb. Ecol. 2009; 57: 413-420. https://doi.org/10.1007/s00248-008-9433-4

[40] Brabban AD, Edwards C. Characterization of growth and product formation by a thermophilic streptomycete grown in a particulate rapemeal-derived liquid medium. J. Appl. Bacteriol. 1996; 80: 651-658. https://doi.org/10.1111/j.1365-2672.1996.tb03270.x

[41] Cohen MF, Yamasaki H, Mazzola M. Brassica napus seed meal soil amendment modifies microbial community structure, nitric oxide production and incidence of Rhizoctonia root rot. Soil Biol. Biochem. 2005; 37: 1215-1227. https://doi.org/10.1016/j.soilbio.2004.11.027

[42] Daeschel MA, Andersson RE, Fleming HP. Microbial ecology of fermenting plant materials. FEMS Microbiol. Rev. 1987 ; 46 : $357-367$.

[43] Yuan WM, Crawford DL. Characterization of Streptomyces lydicus WYEC108 as a potential biocontrol agent against fungal root and seed rots. Appl. Environ. Microbiol. 1995; 61: 3119-3128. https://doi.org/10.1128/aem.61.8.3119-3128.1995

[44] Snapp SS, Date KU, Kirk W, O'Neil K, Kremen A, Bird G. Root, shoot tissues of Brassica juncea and Cereal secale promote potato health. Plant Soil 2007; 294: 55-72. https://doi.org/10.1007/s11104-007-9228-2

[45] Gimsing AL, Kirkegaard JA. Glucosinolates and biofumigation: fate of glucosinolates and their hydrolysis products in soil. Phytochem. Rev. 2009; 8: 299-310. https://doi.org/10.1007/s11101-008-9105-5

[46] Warton B, Matthiessen JN, Roper MR. The soil organisms responsible for the enhanced biodegradation of metham sodium. Biol. Fertil. Soils 2001; 34: 264-269. https://doi.org/10.1007/s003740100410

[47] Andrade OA, Mathre DE, Sands DC. Natural suppression of take-all disease of wheat in Montana soils. Plant Soil 1994 ; $164: 9-18$. https://doi.org/10.1007/BF00010105

[48] Latour X, Corberand T, Laguerre G, Allard F, Lemanceau P. The composition of fluorescent pseudomonad populations associated with roots is influenced by plant and soil type. Appl. Environ. Microbiol. 1996; 62: 2449-2456. https://doi.org/10.1128/aem.62.7.24492456.1996

[49] Arenz BE, Bradeen JM, Otto-Hanson LK, Kinkel LL. Two grass species fail to display differing species-specific effects on soil bacterial community structures after one season of greenhouse growth. Plant Soil 2014; 385: 241-254. https://doi.org/10.1007/s11104-014-2226-2

[50] Lauber CL, Strickland MS, Bradford MA, Fierer N. The influence of soil properties on the structure of bacterial and fungal communities across land-use types. Soil Biol. Biochem. 2008; 40: 2407-2415. https://doi.org/10.1016/j.soilbio.2008.05.021

[51] Mazzola M, Brown J, Izzo AD, Cohen MF. Mechanism of action and efficacy of seed meal-induced pathogen suppression differ in a Brassicaceae species and time-dependent manner. Phytopathology 2007; 97: 454-460. https://doi.org/10.1094/PHYTO-97-4-0454

[52] Kinkel LL, Schlatter DC, Bakker MG, Arenz BE. Streptomyces competition and co-evolution in relation to plant disease suppression. Res. Microbiol. 2012; 163: 490-499. https://doi.org/10.1016/j.resmic.2012.07.005

[53] Lu P, Gilardi G, Gullino ML, Garibaldi A. Biofumigation with Brassica plants and its effect on the inoculum potential of Fusarium yellows of Brassica crops. Eur. J. Plant Pathol. 2010; 126: 387-402. https://doi.org/10.1007/s10658-009-9543-y

[54] Larkin RP, Halloran JM. Management effects of disease-suppressive rotation crops on potato yield and soilborne disease and their economic implication in potato production. Am. J. Potato Res. 2014; 91: 429-439. https://doi.org/10.1007/s12230-014-9366-z

[55] McGuire AM. Mustard green manures replace fumigant and improve infiltration in potato cropping system. Crop Management 2003. Online publication. https://doi.org/10.1094/CM-2003-0822-01-RS

[56] Ramirez RA, Henderson DR, Riga E, Lacey LA, Snyder WA. Harmful effects of mustard bio-fumigants on entomopathogenic nematodes. Biol. Control 2009; 48: 147-154. https://doi.org/10.1016/j.biocontrol.2008.10.010

[57] Brown PD, Morra MJ. Brassicaceae tissues as inhibitors of nitrification in soil. J. Agric. Food Chem. 2009; 57: 7706-7711. https://doi.org/10.1021/jf901516h 